\title{
Pharmaceutical properties of 'sucupira' (Pterodon spp.)
}

\author{
Daiane Hansen ${ }^{1,2, *}$, Mitsue Haraguchi², Antonio Alonso ${ }^{1}$ \\ ${ }^{1}$ Institute of Physics, University Federal of Goiás, ${ }^{2}$ Center of Animal Health, Biological Institute of São Paulo
}

\begin{abstract}
The plant of the genus Pterodon (Fabaceae, Leguminosae), commonly known as 'sucupira' or 'faveira', are disseminated throughout the central region of Brazil and has frequently been used in popular medicine for its anti-rheumatic, analgesic, and anti-inflammatory properties. In recent years, interest in these plants has increased considerably. The biological effects of different phytoextracts and pure metabolites have been investigated in several experimental models in vivo and in vitro. The literature describes flavonoids, triterpene and steroids, while one paper presented studies with proteins isolated from the genus. This review provides an overview of phytochemical and pharmacological research in Pterodon, showing the main chemical compounds studied to date, and focusing on the relationship between these molecules and their biological activity. Furthermore, this study paves the way for more in-depth investigation, isolation and characterization of the molecules of this plant genus.
\end{abstract}

Uniterms: Sucupira. Pterodon/phytochemistry. Pterodon/pharmacognosy. Diterpenes/biological activity. Isoflavones/biological activity. Medicinal plants.

\begin{abstract}
As plantas do gênero Pterodon (Fabaceae/Leguminosae), conhecidas popularmente como "sucupira branca" ou "faveira", encontram-se distribuídas pela região central do Brasil e são frequentemente utilizadas na medicina popular por suas propriedades antirreumáticas, analgésicas e antiinflamatórias. Nos últimos anos, o interesse por estas plantas tem aumentado consideravelmente. Os efeitos biológicos dos diferentes fitoextratos e metabólitos puros têm sido investigados em vários modelos experimentais in vivo e in vitro. A literatura descreve flavonóides, triterpenos, esteróides e apenas um trabalho mostra estudos com proteínas isoladas do gênero. Esta revisão apresenta de maneira geral as investigações farmacológicas e fitoquímicas de Pterodon, mostrando os principais compostos já estudados, sua composição química, focando na relação entre estas moléculas e sua atividade biológica. Mais ainda, nós abrimos as portas para maior investigação, isolamento e caracterização de moléculas deste gênero de plantas.
\end{abstract}

Unitermos: Sucupira. Pterodon/fitoquímica. Pterodon/farmacognosia. Diterpenos/atividade biológica. Isoflavonas/atividade biológica. Plantas medicinais.

\section{INTRODUCTION}

The broad biodiversity within Brazil's territory places the country in a strategic position to develop rational and sustained exploration of new metabolites with therapeutic value. Brazil's landmass covers a wide range of climates, soil types, and altitudes, providing a unique set of selective pressures for the adaptation of plant life in these habitats. The plant chemical diversity is also driven by these forces, in an attempt to best adapt the plant to suit the particular abiotic stresses, fauna, and microbes that

\footnotetext{
*Correspondence: D. Hansen. Centro de P\&D de Sanidade Animal, Instituto Biológico. Av. Conselheiro Rodrigues Alves, 1252 - Vila Mariana - 04014-002 - São Paulo - SP, Brazil. E-mail: daianehansen31@hotmail.com
}

coexist in the environment. Certain areas of vegetation, such as the Amazonian Forest, Atlantic Forest, Cerrado (Brazilian Savanna), and Caatinga, are rich in biodiversity and are therefore of great interest for the discovery of natural compounds with biological activity against diseases (Basso et al., 2005).

The vegetal genus Pterodon spp., belonging to the Fabaceae (=Leguminosae)/ Faboideae subfamily, is popularly known in Brazil as 'sucupira branca' or 'faveira' and comprises four native species: Pterodon abruptus Benth., Pterodon apparicioi Pedersoli., Pterodon polygalaeflorus Benth. and, Pterodon emarginatus Vogel. (synonym Pterodon pubescens Benth.). Interestingly, the species Pterodon emarginatus and Pterodon pubescens are in fact the same plant species. In 1862 this plant was 
classified as Pterodon pubescens by Bentham, but Vogel subsequently demonstrated that it was in fact the same plant species as that of Pterodon emarginatus. The species now bears the official name of Pterodon emarginatus Vogel. Unfortunately, it is commonly misidentified as being two distinct species (Carvalho, 2004).

In general, these species are native aromatic trees reaching 5-10 $\mathrm{m}$ in height distributed throughout the central region of Brazil (Goiás, Minas Gerais and São Paulo) (Oliveira, Paiva, 2005; Dutra et al., 2008a). These trees frequently grow in the Brazilian Cerrado and in transitional areas approaching the Paraná River basin's semi-deciduous forest. Despite their slow growth, these species are important in mixed reforestations designed to recover degraded areas (Oliveira, Paiva, 2005), due to their tolerance for direct sunlight and low soil fertility.

In mature seeds of some species, such as Pterodon emarginatus (Vogel), a distinguishing characteristic is the frequent presence of phenolic compounds in the integuments. Tests on these compounds have demonstrated their contribution to great hardness, low water permeability and high resistance to pathogen attack (Suárez, Engleman, 1980). Also, in mature seeds, the embryo show fleshy cotyledons, with accumulated lipid and protein reserves.

Although the 'sucupira' seeds are commercially available at the medicinal flora market and are widely used in domestic medicine for their anti-rheumatic (Sabino et al., 1999b; Coelho et al., 2004), analgesic (Coelho et al., 2005) and anti-inflammatory (Carvalho et al., 1999; Dutra et al., 2009) properties, only a small number of papers have described the various flavonoids, amino-containing, triterpene, steroid, and others secondary compounds present in the Pterodon genus. In addition, to the best of our knowledge, there is only one report available in the literature showing studies with proteins isolated from this genus, a $5 \mathrm{kDa} \alpha$-amylase inhibitor reported by Silva et al. (2007). In this review, we have described the main chemical compounds studied to date and focused on establishing a relationship between these molecules and their biological activity. The Tables I to V summarize the main molecules published in the literature.

\section{Chemistry}

The interest in the Pterodon genus began in the sixties, when Mors et al. (1967) isolated the geranylgeraniol 21 (Table IV) and 14,15-epoxigeranylgeraniol 23 (Table IV) by extraction of $P$. pubescens fruit essential oil with hexane, followed by chromatography on silica gel. In 1970 , diterpenoids $(2,13)$ were obtained from the fruits of $P$. emarginatus by extraction with petroleum ether by Mahajan and Monteiro. (Table III). Two years later, the same authors presented a new compound from the same fruit (19). All these molecules present a vouacapane skeleton in their structures. Yet in 1970, Fascio et al., isolated new terpenes from $P$. pubescens fruit oil $(7,14)$ (Table III). In 1975, diterpenoid 20 was isolated from the same species. This compound shows high biological activity against S.mansoni cercariae and inhibits Crithidia fasciculate in culture (Fascio et al., 1975).

Braz Filho et al. (1971), based on a chemical study of Brazilian leguminosae, isolated isoflavones from trunk wood of $P$. pubescens. The IR, UV and NMR spectrum identified the compound $\mathrm{C}_{20} \mathrm{H}_{20} \mathrm{O}_{7}$, and more specifically the molecules $3^{\prime}, 4^{\prime}, 6,7$ tetramethoxyisoflavone (33), 2',6,7-trimethoxy-4',5' methylenedioxyisoflavone

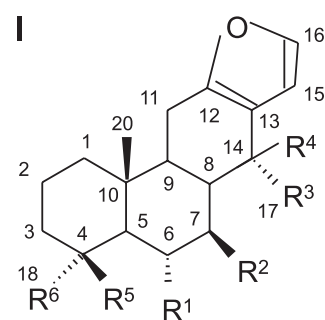

19<smiles></smiles>

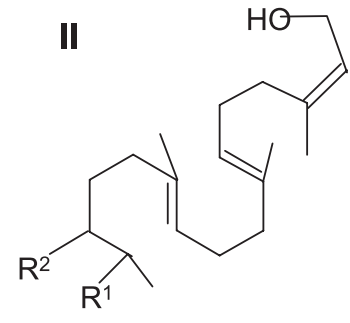

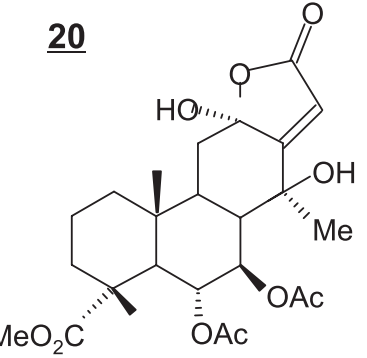<smiles>[R]c1cc(-c2coc3c([R])c([R])c([R])cc3c2=O)cc([R])c1[R]</smiles><smiles>O=C1c2c(O)cc(O)cc2OC(c2ccc(O)c(O)c2)[C@@H]1O</smiles> 
(38), the isomeric 2', 3', 4',6,7-penta methoxyisoflavone and 2',4',5',6,7-pentamethoxyisoflavone (40), and 2',4',5',6,7-pentamethoxyisoflavone (39). All of these molecules are shown in Table V.

The seed of $P$. emarginatus was shown to contain sesquiterpenic essential oil such as trans- $\beta$-caryophyllene $(35.9 \%)$, $\beta$-elemene $(15.3 \%)$, germacrene D $(9.8 \%)$, spathulenol (5.9\%), $\alpha$-humulene $(6.8 \%)$ and, bicyclogermacrene (5.5\%) (Dutra et al. 2008a, 2009).

From the P. polygalaeflorus Benth. species, four fu- ran diterpenes $(12,15,17,18)$ were described by Fascio et al. (1975). The $6 \alpha$-7 $\beta$-dihydroxyvouacapan- $17 \beta$ oate (8) was demonstrated to have important biological activities (Nunan et al., 1982; Duarte et al., 1996). In addition to the phytochemical study of the above-referenced species, the diterpenes $6 \alpha$-hydroxyvoucapane (3), methyl $6 \alpha$, $7 \beta$-dihydroxyvoucapan-17 $\beta$-oate (8) and, vouacapane$6 \alpha, 7 \beta, 14 \beta, 19$-tetraol (5) were also isolated from seeds by Arriaga et al., 2000. The same authors elucidated the structure of taxifolin (dihydroquercetin), the most com-

TABLE I - Biological activities in vivo of Pterodon spp. plant extracts/vouacapan derivative

\begin{tabular}{|c|c|c|c|}
\hline Treatment & Dose & Activity & References \\
\hline \multicolumn{4}{|c|}{ P. pubescens / P. emarginatus } \\
\hline HAE & 5 or $50 \mathrm{mg} / \mathrm{kg}$ & anti-rheumatic/anti-arthritic & Sabino et al., 1999b \\
\hline $\mathrm{HE}$ & $500 \mathrm{mg} / \mathrm{kg}$ & $\begin{array}{l}\text { anti-inflammatory; } \\
\text { determination of } \mathrm{ED}_{50}\end{array}$ & Carvalho et al., 1999 \\
\hline OEP & $\begin{array}{c}40 \mu \mathrm{g} ; 200 \mu \mathrm{g} \text { and } 200 \mathrm{mg} / \mathrm{kg} \\
\text { (OEP). }\end{array}$ & anti-inflammatory & Silva et al., 2004 \\
\hline Fractions PF1, PF2, PF3, PF4 & $2 ; 20$ and $200 \mu \mathrm{g} / \mathrm{kg}$ & anti-inflammatory & Silva et al., 2004 \\
\hline Fractions PF1.1, PF1.2, PF1.3 & $0.1 ; 1.0$ and $10 \mu \mathrm{g} / \mathrm{kg}$ & anti-inflammatory & Silva et al., 2004 \\
\hline $\begin{array}{c}\text { OEP and fractions PF1, PF2, } \\
\text { PF3 and PF4 }\end{array}$ & $0.0013-130 \mathrm{mg} / \mathrm{kg}$ & anti-nociceptive & Coelho et al., 2004 \\
\hline $\mathrm{EO}, \mathrm{HE}, \mathrm{BE}$ and $\mathrm{ME}$ & $100-500 \mathrm{mg} / \mathrm{kg}$ & anti-nociceptive & Dutra et al., 2008a \\
\hline $\mathrm{EO}$ & 100,300 and $500 \mathrm{mg} / \mathrm{kg}$ & $\begin{array}{l}\text { anti-ulcerogenic and anti- } \\
\text { inflammatory }\end{array}$ & Dutra et al., 2009c \\
\hline $\mathrm{EE}$ & $0.1 ; 0.3$ and $1 \mathrm{~g} / \mathrm{kg}$ & $\begin{array}{l}\text { anti-nociceptive and anti- } \\
\text { inflammatory }\end{array}$ & Moraes et al., 2009 \\
\hline \multicolumn{4}{|c|}{ P. polygalaeflorus } \\
\hline $\begin{array}{c}6 \alpha, 7 \beta \text {-dihydroxyvouacapan-17 } \\
\beta \text {-oate }\end{array}$ & $200 \mu \mathrm{mol} / \mathrm{kg}$ & anti-nociceptive & Nunan et al., 1982 \\
\hline $\begin{array}{c}6 \alpha, 7 \beta \text {-dihydroxyvouacapan-17 } \\
\beta \text {-oate }\end{array}$ & $125 ; 250$ and $500 \mu \mathrm{mol} / \mathrm{kg}$ & anti-nociceptive & Duarte et al., 1992 \\
\hline $\begin{array}{c}6 \alpha, 7 \beta \text {-dihydroxyvouacapan-17 } \\
\beta \text {-oate }\end{array}$ & $250 ; 375$ and $500 \mu \mathrm{mol} / \mathrm{kg}$ & anti-nociceptive & Duarte et al., 1992 \\
\hline $\begin{array}{c}6 \alpha, 7 \beta \text {-dihydroxyvouacapan-17 } \\
\beta \text {-oate }\end{array}$ & 250 and $500 \mu \mathrm{mol} / \mathrm{kg}$ & anti-nociceptive & Duarte et al., 1992 \\
\hline $\begin{array}{c}6 \alpha, 7 \beta \text {-dihydroxyvouacapan-17 } \\
\beta \text {-oate }\end{array}$ & 125 and $500 \mu \mathrm{mol} / \mathrm{kg}$ & anti-nociceptive & Duarte et al., 1996 \\
\hline HAE & $100,200,400 \mathrm{mg} / \mathrm{kg}$ & $\begin{array}{l}\text { anti-nociceptive, anti- } \\
\text { inflammatory and } \\
\text { bronchodilator }\end{array}$ & Leal et al., 2000 \\
\hline $\begin{array}{c}\text { HE, ME, EO and } \\
6 \alpha \text {-acetoxyvouacapan }\end{array}$ & $12.5-500 \mu \mathrm{g} / \mathrm{mL}$ & larvicidal on Aedes aegypti & Pimenta et al., 2006 \\
\hline EO & $100-1300 \mu \mathrm{g} / \mathrm{mL}$ & effects on contractions & Evangelista et al., 2007 \\
\hline EO & $100-300 \mu \mathrm{g} / \mathrm{mL}$ & antispasmodic & Leonhardt et al., 2010 \\
\hline
\end{tabular}

BE: buthanolic extract; EE: ethanolic extract; EO: essential oil; HAE: hydro-alcoholic extract; HE: hexanic extract; ME: methanolic extract; OEP: oleaginous extract 
TABLE II - Biological activities in vitro of Pterodon spp. plant extracts/vouacapan derivative

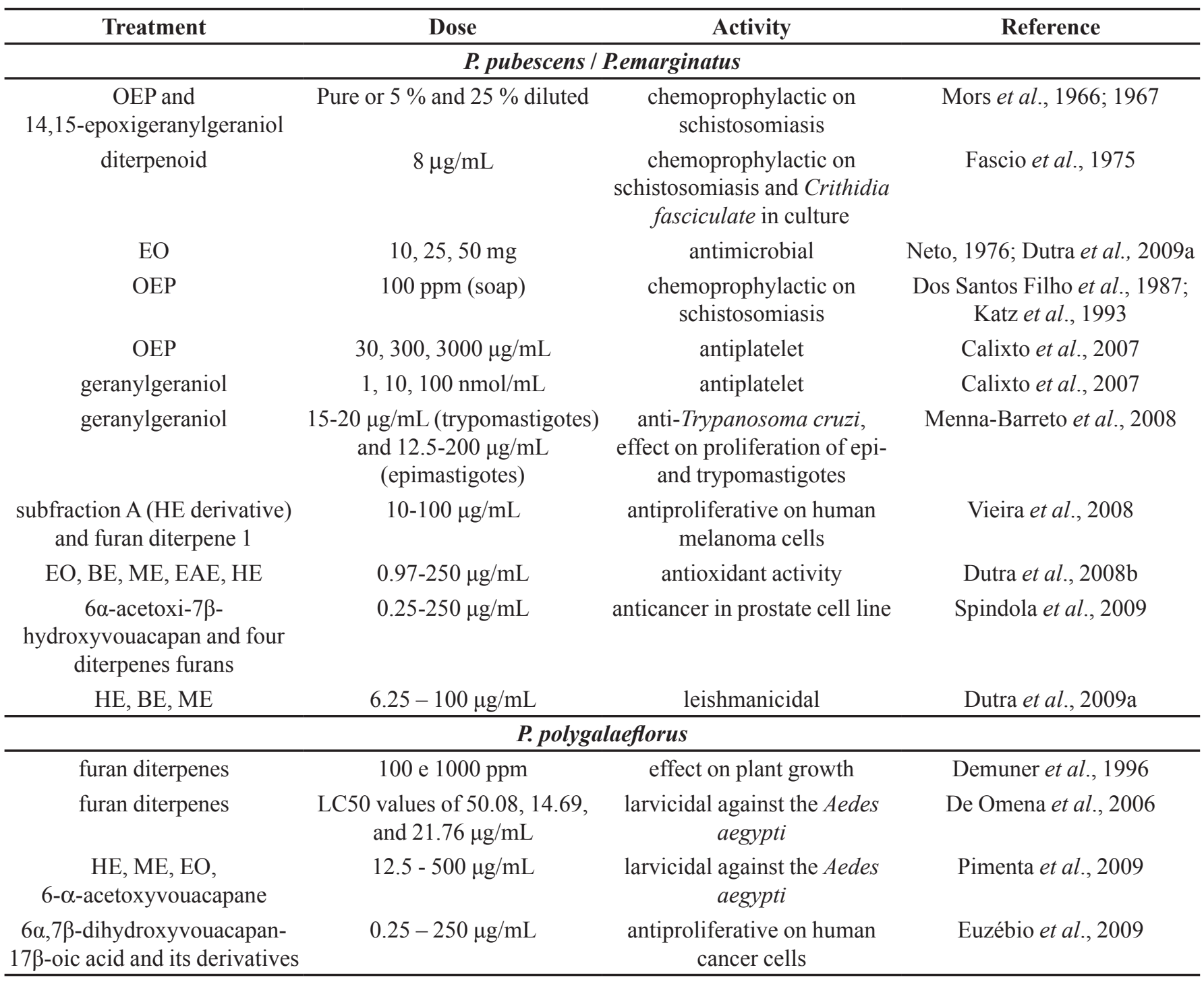

BE: buthanolic extract; EAE: ethyl acetate extract; EO: essential oil; HE: hexanic extract; ME: methanolic extract; OEP: oleaginous extract

mon member of the dihydroflavonol group (41). Details of these molecules are shown in Table III.

4-methoxybenzoic acid ( $p$-anisic acid) and triterpenes (lupeol and betulin) were isolated from the heartwood of $P$. polygalaeflorus (Marques et al., 1998). Sesquiterpenic essential oils were obtained from fruits and demonstrated to contain trans- $\beta$-caryophyllene $(20.6 \%)$ followed by spathulenol $(16.6 \%), \alpha$-capaene $(10.4 \%)$, $\gamma$-muurolene (8.1\%), $\beta$-elemene, $\alpha$-humulene, alloaromadendrene, bicyclogermacrene, $\delta$-cadinene, $\alpha$-cubenene, $\gamma$-cadinene, $\beta$-gurjunene, aromadendrene, germacrene $\mathrm{D}$, $\alpha$-calacorene, $\delta$-elemene, and $\alpha$-gurjunene (Campos et al., 1994; Evangelista et al., 2007).

There are several papers referring to the isolation of alkaloid molecules of the Pterodon genus (Sabino et al., 1999a; Coelho et al., 2005; Dutra et al., 2008a,b; Menna-Barreto et al., 2008; Vieira et al., 2008; Dutra et al., 2009b) but only one paper showed the structures of homoormosanine-type alkaloids from Bowdichia virgiloides, popularly called 'black sucupira' or 'sucupira preta' (Torrenegra et al., 1989).

\section{Biological properties}

The active metabolites were isolated at the same time that the medicinal properties were investigated. In folk medicine, wine infusions from Pterodon genus seeds are used in the treatment of rheumatoid arthritis, an autoimmune disease characterized by chronic inflamed joints and exacerbated functions of macrophages and $\mathrm{T}$ and $\mathrm{B}$ 
TABLE III - Structure of the diterpenes based on molecule I, identified from the Pterodon genus

\begin{tabular}{|c|c|c|c|c|c|c|c|c|}
\hline Diterpenes I & $\mathrm{R}^{1}$ & $\mathrm{R}^{2}$ & $\mathrm{R}^{3}$ & $\mathrm{R}^{4}$ & $\mathrm{R}^{5}$ & $\mathrm{R}^{6}$ & Species & References \\
\hline 1 & $\mathrm{H}$ & $\mathrm{H}$ & $(\alpha) \mathrm{Me}$ & $(\beta) \mathrm{H}$ & $\mathrm{Me}$ & $\mathrm{Me}$ & Ppo & Pimenta et al. 2006 \\
\hline 2 & $\mathrm{H}$ & OAc & $(\alpha) \mathrm{Me}$ & ( $\beta) \mathrm{H}$ & $\mathrm{Me}$ & $\mathrm{Me}$ & Pe, Ppu & $\begin{array}{l}\text { Mahajan, Monteiro, } 1970 \\
\text { 1973; Spindola et al., } 2009\end{array}$ \\
\hline 3 & $\mathrm{OH}$ & $\mathrm{H}$ & $(\alpha) \mathrm{Me}$ & ( $\beta) \mathrm{H}$ & $\mathrm{Me}$ & $\mathrm{Me}$ & Ppo & $\begin{array}{l}\text { Arriaga et al., 2000; Pimenta } \\
\text { et al., } 2006\end{array}$ \\
\hline 4 & $\mathrm{OH}$ & $\mathrm{OH}$ & $(\alpha) \mathrm{Me}$ & ( $\beta) \mathrm{OH}$ & $\mathrm{Me}$ & $\mathrm{Me}$ & Pe, Ppo & $\begin{array}{l}\text { Mahajan, Monteiro, } 1973 \text {; } \\
\text { Fascio et al., 1975; Demuner } \\
\text { et al., } 1996\end{array}$ \\
\hline 5 & $\mathrm{OH}$ & $\mathrm{OH}$ & $(\alpha) \mathrm{Me}$ & ( $\beta) \mathrm{OH}$ & $\mathrm{CH}_{2} \mathrm{OH}$ & $\mathrm{Me}$ & Ppo & $\begin{array}{l}\text { Arriaga et al., 2000; Demuner } \\
\text { et al.,1996 }\end{array}$ \\
\hline 6 & $\mathrm{OH}$ & $\mathrm{OH}$ & $(\alpha) \mathrm{H}$ & (ß) $\mathrm{CH}_{2} \mathrm{OH}$ & $\mathrm{Me}$ & $\mathrm{Me}$ & Ppu & Spindola et al., 2009 \\
\hline 7 & $\mathrm{OH}$ & $\mathrm{OH}$ & $(\alpha) \mathrm{H}$ & $(\beta) \mathrm{COOH}$ & $\mathrm{Me}$ & $\mathrm{Me}$ & $\begin{array}{l}\text { Pe, Ppu, } \\
\text { Ppo }\end{array}$ & $\begin{array}{l}\text { Mahajan, Monteiro, 1972; } \\
\text { 1973; Fascio et al., } 1975\end{array}$ \\
\hline 8 & $\mathrm{OH}$ & $\mathrm{OH}$ & $(\alpha) \mathrm{H}$ & ( $\beta) \mathrm{COOMe}$ & $\mathrm{Me}$ & $\mathrm{Me}$ & $\begin{array}{l}\text { Pe, Ppo, } \\
\text { Ppu }\end{array}$ & $\begin{array}{l}\text { Mahajan, Monteiro, 1972; } \\
\text { 1973; Fascio et al., 1975; } \\
\text { Arriaga et al., 2000; Spindola } \\
\text { et al. } 2009\end{array}$ \\
\hline 9 & $\mathrm{OH}$ & OAc & $(\alpha) \mathrm{H}$ & ( $\beta$ ) $\mathrm{COOMe}$ & $\mathrm{Me}$ & $\mathrm{Me}$ & Pe, Ppo & $\begin{array}{l}\text { Mahajan, Monteiro, 1972; } \\
1973\end{array}$ \\
\hline 10 & OAc & $\mathrm{H}$ & $(\alpha) \mathrm{Me}$ & ( $\beta) \mathrm{H}$ & $\mathrm{Me}$ & $\mathrm{Me}$ & Ppo & Pimenta et al., 2006 \\
\hline 11 & OAc & $\mathrm{OH}$ & $(\alpha) \mathrm{Me}$ & ( $\beta) \mathrm{H}$ & $\mathrm{Me}$ & $\mathrm{Me}$ & $\mathrm{Ppu}$ & Spindola et al. 2009 \\
\hline 12 & OAc & $\mathrm{OH}$ & $(\alpha) \mathrm{H}$ & ( $\beta$ ) $\mathrm{COOMe}$ & $\mathrm{Me}$ & $\mathrm{Me}$ & Ppo & Fascio et al., 1975 \\
\hline 13 & OAc & OAc & $(\alpha) \mathrm{Me}$ & $(\beta) \mathrm{H}$ & $\mathrm{Me}$ & $\mathrm{Me}$ & $\mathrm{Pe}, \mathrm{Ppu}$ & $\begin{array}{l}\text { Mahajan, Monteiro, 1972; } \\
\text { 1973; Spindola et al., } 2009\end{array}$ \\
\hline 14 & OAc & OAc & $(\alpha) \mathrm{Me}$ & ( $\beta) \mathrm{OH}$ & COOMe & $\mathrm{Me}$ & $\mathrm{Ppu}$ & Fascio et al., 1970 \\
\hline 15 & OAc & OAc & $(\alpha) \mathrm{Me}$ & ( $\beta) \mathrm{OH}$ & $\mathrm{Me}$ & COOMe & $\mathrm{Ppu}$ & Fascio et al., 1975 \\
\hline 16 & OAc & OAc & $\mathrm{C}=\mathrm{CH}_{2}$ & & $\mathrm{Me}$ & $\mathrm{Me}$ & $\mathrm{Pe}$ & Mahajan, Monteiro, 1973 \\
\hline 17 & OAc & OAc & $\mathrm{H}$ & $\mathrm{CHO}$ & $\mathrm{Me}$ & $\mathrm{Me}$ & $\mathrm{Ppu}$ & Fascio et al., 1975 \\
\hline 18 & $\mathrm{OAc}$ & OAc & $\mathrm{H}$ & COOMe & $\mathrm{Me}$ & $\mathrm{Me}$ & $\mathrm{Ppu}$ & Fascio et al., 1975 \\
\hline
\end{tabular}

Ppo: Pterodon polygalaeflorus; Pe: Pterodon emarginatus; Ppu: Pterodon pubescens

TABLE IV - Structure of the diterpenes based on molecule II, identified from the Pterodon genus

\begin{tabular}{|c|c|c|c|}
\hline Diterpenes II & $\mathrm{R}^{1}$ & $\mathrm{R}^{2}$ & References \\
\hline 21 & & & Mors et al., 1967 \\
\hline 22 & & & Mors et al., 1967 \\
\hline 23 & & & Mors et al., 1967 \\
\hline
\end{tabular}

lymphocytes (Cardoso et al., 2008). Sabino et al. (1999b) and Coelho et al. (2004) have demonstrated the antiarthritic effect of hydro-alcoholic extract of P. pubescens seeds using the collagen-induced arthritis model (Table I). Also, these researchers have presented studies in vitro and in vivo demonstrating that acute administration of even extremely high doses of the oil of $P$. pubescens seeds are non-mutagenic, non-toxic, and non-cytotoxic to human peripheral blood mononuclear cells (PBMNCs) (Sabino et al., 1999a). In subsequent work, sub-acute toxic effects were not observed with hydro-alcoholic extract in studies of hematological, histopathological, clinical, and biochemical parameters in arthritic mice, according to studies of Coelho et al. (2001). Further analysis revealed the anti-inflammatory (Silva et al., 2004) and anti-nociceptive effects of ethanolic extracts of $P$. pubescens seeds, confirming the rationale behind the use of this plant in popular medicine to treat pain disorders (Coelho et al., 2005) (Table I).

The investigations on the pharmacological properties of 'sucupira' surpass those of its anti-inflammatory and anti-rheumatic activities. Dutra et al. (2008b) studied the total phenolic content and antioxidant activity of seeds of P. emarginatus (Table II). The phenolic constituents found 
TABLE V - Structure of the isoflavones based on molecule III, identified from the Pterodon genus

\begin{tabular}{|c|c|c|c|c|c|c|c|c|c|}
\hline $\begin{array}{c}\text { Isoflavones } \\
\text { III }\end{array}$ & $\mathrm{R}^{1}$ & $\mathrm{R}^{2}$ & $\mathrm{R}^{3}$ & $\mathrm{R}^{4}$ & $\mathrm{R}^{5}$ & $\mathrm{R}^{6}$ & $\mathrm{R}^{7}$ & Species & References \\
\hline 24 & $\mathrm{H}$ & $\mathrm{H}$ & $\mathrm{OH}$ & $\mathrm{H}$ & $\mathrm{H}$ & $\mathrm{OH}$ & $\mathrm{H}$ & $\mathrm{Pa}$ & Galina, Gottlieb, 1974 \\
\hline 25 & $\mathrm{H}$ & $\mathrm{H}$ & $\mathrm{OMe}$ & $\mathrm{H}$ & $\mathrm{H}$ & $\mathrm{OMe}$ & $\mathrm{H}$ & $\mathrm{Pa}$ & Galina, Gottlieb, 1974 \\
\hline 26 & $\mathrm{H}$ & $\mathrm{H}$ & $\mathrm{OMe}$ & $\mathrm{H}$ & $\mathrm{OMe}$ & $\mathrm{OH}$ & $\mathrm{H}$ & $\mathrm{Pa}$ & Galina, Gottlieb, 1974 \\
\hline 27 & $\mathrm{H}$ & $\mathrm{H}$ & $\mathrm{OMe}$ & $\mathrm{H}$ & $\mathrm{OMe}$ & $\mathrm{OH}$ & $\mathrm{H}$ & $\mathrm{Pa}$ & Galina, Gottlieb, 1974 \\
\hline 28 & $\mathrm{H}$ & $\mathrm{H}$ & $-\mathrm{O}-\mathrm{CH}$ & $2-\mathrm{O}-$ & $\mathrm{H}$ & $\mathrm{OMe}$ & $\mathrm{H}$ & $\mathrm{Pa}$ & Galina, Gottlieb, 1974 \\
\hline 29 & $\mathrm{H}$ & $\mathrm{OH}$ & $\mathrm{OMe}$ & $\mathrm{H}$ & $\mathrm{OMe}$ & $\mathrm{OH}$ & $\mathrm{H}$ & $\mathrm{Pa}$ & Galina, Gottlieb, 1974 \\
\hline 30 & $\mathrm{H}$ & $-\mathrm{O}-\mathrm{CH}$ & $\mathrm{H}_{2}-\mathrm{O}-$ & $\mathrm{H}$ & $\mathrm{OMe}$ & $\mathrm{OH}$ & $\mathrm{H}$ & Pa, Ppo & $\begin{array}{l}\text { Galina, Gottlieb, 1974; } \\
\text { Marques et al., } 1998\end{array}$ \\
\hline 31 & $\mathrm{H}$ & $-\mathrm{O}-\mathrm{CH}$ & $\mathrm{H}_{2}-\mathrm{O}-$ & $\mathrm{H}$ & $\mathrm{OMe}$ & $\mathrm{OMe}$ & $\mathrm{H}$ & Ppo & Marques et al., 1998 \\
\hline 32 & $\mathrm{H}$ & OMe H & & $\mathrm{H}$ & $\mathrm{OMe}$ & $\mathrm{OMe}$ & $\mathrm{H}$ & Ppo & Marques et al., 1998 \\
\hline 33 & $\mathrm{H}$ & $\mathrm{OMe}$ & $\mathrm{OMe}$ & $\mathrm{H}$ & $\mathrm{OMe}$ & $\mathrm{OMe}$ & $\mathrm{H}$ & $\mathrm{Pa}, \mathrm{Ppu}$ & $\begin{array}{l}\text { Braz Filho et al., 1971; } \\
\text { Galina, Gottlieb, 1974; } \\
\text { Marques et al., } 1998\end{array}$ \\
\hline 34 & $\mathrm{H}$ & $\mathrm{OMe}$ & $\mathrm{OMe}$ & $\mathrm{OMe}$ & $\mathrm{OMe}$ & $\mathrm{OMe}$ & $\mathrm{H}$ & $\mathrm{Pa}$ & Almeida, Gottlieb, 1975 \\
\hline 35 & $\mathrm{OMe}$ & $\mathrm{H}$ & $\mathrm{OMe}$ & $\mathrm{OMe}$ & $\mathrm{OMe}$ & $\mathrm{OH}$ & $\mathrm{H}$ & $\mathrm{Pa}$ & Galina, Gottlieb, 1974 \\
\hline 36 & $\mathrm{OMe}$ & $\mathrm{H}$ & $-\mathrm{O}-\mathrm{CH}$ & $2-\mathrm{O}-$ & $\mathrm{H}$ & $\mathrm{OMe}$ & $\mathrm{H}$ & $\mathrm{Pa}$ & Galina, Gottlieb, 1974 \\
\hline 37 & $\mathrm{OMe}$ & $\mathrm{H}$ & $-\mathrm{O}-\mathrm{CH}$ & $2-\mathrm{O}-$ & $\mathrm{H}$ & $\mathrm{OMe}$ & $\mathrm{OMe}$ & $\mathrm{Pa}$ & Galina, Gottlieb, 1974 \\
\hline 38 & $\mathrm{OMe}$ & $\mathrm{H}$ & $-\mathrm{O}-\mathrm{CH}$ & $-\mathrm{O}-$ & $\mathrm{OMe}$ & $\mathrm{OMe}$ & $\mathrm{H}$ & $\begin{array}{l}\text { Pa, Ppo, } \\
\text { Ppu }\end{array}$ & $\begin{array}{l}\text { Galina, Gottlieb, 1974; } \\
\text { Braz Filho et al.,1971; } \\
\text { Marques et al., 1998 }\end{array}$ \\
\hline 39 & $\mathrm{OMe}$ & $\mathrm{H}$ & $\mathrm{OMe}$ & $\mathrm{OMe}$ & $\mathrm{OMe}$ & $\mathrm{OMe}$ & $\mathrm{H}$ & $\begin{array}{l}\text { Pa, Ppo, } \\
\text { Ppu }\end{array}$ & $\begin{array}{l}\text { Galina, Gottlieb, 1974; } \\
\text { Marques et al., } 1998\end{array}$ \\
\hline 40 & $\mathrm{OMe}$ & $\mathrm{OMe}$ & $\mathrm{OMe}$ & $\mathrm{H}$ & $\mathrm{OMe}$ & $\mathrm{OMe}$ & $\mathrm{H}$ & $\begin{array}{l}\text { Pa, Ppo, } \\
\text { Ppu }\end{array}$ & $\begin{array}{l}\text { Almeida, Gottlieb, 1975; } \\
\text { Braz Filho et al., 1971; } \\
\text { Marques et al., } 1998\end{array}$ \\
\hline
\end{tabular}

Pa: Pterodon apparicioi; Ppo: Pterodon polygalaeflorus; Ppu: Pterodon pubescens

in vegetables have attracted considerable attention because of their antioxidant activity. The antioxidant activities of phenolics are mainly due to their redox properties, which allow them to act as reducing agents, hydrogen donors, and singlet oxygen quenchers. They have a metal chelation potential and play an important role in the adsorption or neutralization of free radicals. Buthanolic and methanolic fractions of the $P$. emarginatus seeds demonstrated a marked scavenging effect on DPPH radical (2,2-diphenyl2-picrylhydrazyl hydrate).

Other studies have demonstrated the potential trypanocidal effect of the oleaginous ethanolic extract of P. pubescens seeds and its fractions (Menna-Barreto et al., 2008) (Table II). Trypanosoma cruzi is the causative agent of Chagas' disease, the parasitic infection that remains one of the leading causes of heart diseases in Latin America. Current treatment options for this disease involve two nitroheterocyclic compounds that present low efficacy and severe side effects. It is hoped that antiparasitic therapeutic agents can be identified from the plants through screening efforts aimed at discovering new molecules such as natural products, proteins and, peptides with recognized biological activity (Araújo et al., 2005; Hansen et al., 2007).

Also in the area of parasitic diseases, a group of Brazilian researchers demonstrated that the P. pubescens fruit essential oil inhibited the penetration of the cercaries of Schistosoma mansoni (Dos Santos-Filho et al., 1972, 1987; Katz et al., 1993). One of the compounds identified as a component of this oil was the 14,15- epoxigeranylgeraniol (3), a molecule isolated by Mors et al. (1967), and shown to be effective as a chemoprophyloactic agent in schistosomiasis. Mahajan and Monteiro (1973) also investigated the anti-cercaria action of $P$. pubescens while the other three species were studied by Fascio et al. (1975) (Table II). 
Further biological activity data was presented by Neto (1973) during his doctoral research. He demonstrated that the oil obtained from $P$. pubescens seeds presented significant in vitro antimicrobial activity (Table II).

From the $P$. polygalaeflorus species, the diterpene $6 \alpha-7 \beta$-dihydroxyvouacapan-17 $\beta$-oate was demonstrated to have an anti-inflammatory activity in the paw edema produced by carrageenin (Nunan et al., 1982) and, in subsequent studies, showed an important anti-nociceptive activity (Duarte et al., 1996) (Table I). The ethanolic extract from seeds showed significant larvicidal activity against the Aedes aegypti mosquito (De Omena et al., 2006) (Table II) and the hydro-alcoholic extract was the most active bronchodilator among those plants widely used in north-eastern Brazil for respiratory tract diseases (Leal et al., 2000) (Table I).

\section{Toxicology}

A paper written by Sabino et al. (1999a) presented a study in which the oil of $P$. pubescens seeds $(\mathrm{PpSO})$ was tested for acute toxicity, mutagenic activity and cytotoxicity against human peripheral blood mononuclear cells (PBMNC). The study provided data to classify $\mathrm{PpSO}$ as non-cytotoxic to PBMNC, non-mutagenic and, nontoxic after acute administration, since the PpSO doses tested were significantly higher than those used by the population.

Also, the clastogenicity of 'sucupira oil' extracted from P. pubescens was tested in vivo on wistar rat bone marrow cells. Metaphase analysis showed that the compound did not induce a significant increase in the frequencies of chromosomal aberrations (Dias et al., 1995).

\section{CONCLUSION}

The broad biodiversity in Brazil places the country in a strategic position in the development and rational exploitation of new metabolites with therapeutic value. Areas of vegetation such as the Central Cerrado are rich in species of value in the search for natural compounds with activity against many diseases. The chemical characterization of these compounds, the determination of their mechanism of action and, the study of biological activities in vitro and in vivo, have yielded important information about the natural compounds and their derivatives.

The aim of this review was to present the studies involving the genus Pterodon and its natural compounds, with the goal of encouraging further investigation of these plants. The isolation and characterization of new molecules, and their correlation with new biological tests, provides fertile ground for the development of drugs for a large number of diseases.

\section{ACKNOWLEDGMENTS}

The authors would like to thank Dr. Kelly Boatright Sexton from North Carolina State University for reviewing the manuscript and are grateful to Mr. Randolfo Carneiro Carvalho (Fazenda Eldorado, Urutaí, GO, Brazil) for incentive and popular information regarding the therapeutical properties of 'sucupira' seeds. CAPES/PNPD and CNPq provided financial support.

\section{REFERENCES}

ALMEIDA, M.E.L.; GOTTLIEB, O.R. Further isoflavones. Pterodon apparicioi. Phytochemistry, v.14, n.12, p.2716, 1975.

ARAÚJO, A.P.U.; HANSEN, D.; VIEIRA, D.F.; OLIVEIRA, C.; SANTANA, L.A.; BELTRAMINI, L.M.; SAMPAIO, C.A.M.; SAMPAIO, M.U.; OLIVA, M.L.V. Kunitz type Bauhinia bauhinioides inhibitors devoid of disulfide bridges: isolation of the cDNAs, heterologous expression and structural studies. Biol. Chem., v.386, n.6, p.561-568, 2005.

ARRIAGA, A.M.C.; CASTRO, M.A.B.; SILVEIRA, E.R.; BRAZ-FILHO, R. Further diterpenoids isolated from Pterodon polygalaeflorus. J. Braz. Chem. Soc., v.11, n.2, p.187-190, 2000.

BASSO, L.A.; PEREIRA DA SILVA, L.H.; FETT-NETO, A.G.; AZEVEDO JR, W.F.; MOREIRA, I.S.; PALMA, M.S.; CALIXTO, J.B.; ASTOLFI FILHO, S.; DOS SANTOS, R.R.; SOARES, M.B.P.; SANTOS, D.S. The use of biodiversity as source of new chemical entities against defined molecular targets for treatment of malaria, tuberculosis, and T-cell mediated diseases- a review. Mem. Inst. Oswaldo Cruz, v.100, n.6, p.575-606, 2005.

BRAZ FILHO, R.; GOTTLIEB, O.R.; ASSUMPÇÃO, R.M.V. Chemistry of Brazilian Leguminosae. XXXIV Isoflavones of Pterodon pubescens. Phytochemistry, v.10, n.11, p.28352836, 1971.

CALIXTO, N.O.; COSTA E SILVA, M.C.; GAYER, C.R.; COELHO, M.G.; PAES, M.C.; TODESCHINI, A.R. Antiplatelet activity of geranylgeraniol isolated from Pterodon pubescens fruit oil is mediated by inhibition of cyclooxigenase-1. Planta Med., v.73, n.5, p.480-483, 2007. 
CAMPOS, A.M.; SILVEIRA, E.R.; BRAZ-FILHO, R.; TEIXEIRA, T.C. Diterpenoids from Pterodon polygalaeflorus. Phytochemistry, v.36, n.2, p.403-406, 1994.

CARDOSO, C.C.; PINTO, A.C.; MARQUES, P.R.; GAYER, C.R.M.; AFEL, M.I.R.; COELHO, M.G.P.; SABINO, K.C.C. Suppression of T and B cell responses by Pterodon pubescens seeds ethanolic extract. Pak. J. Biol. Sci., v.11, n.19, p.2308-2313, 2008.

CARVALHO, J.C.T.; SERTIÉ, J.A.A.; BARBOSA, M.V.J.; PATRÍCIO, K.C.M.; CAPUTO, L.R.G.; SARTI, S.J.; FERREIRA, L.P.; BASTOS, J.K. Anti-inflammatory activity of the crude extract from the fruits of Pterodon emarginatus Vog. J. Ethnopharmacol., v.64, n.2, p.127$133,1999$.

CARVALHO, J.C.T. Sucupira, Pterodon emarginatus Vog. In: CARVALHO, J.C.T. Fitoterápicos anti-inflamatórios - aspectos químicos, farmacológicos e aplicações terapêuticas. Ribeirão Preto: Tecmedd, 2004. p.383.

COELHO, M.G.P.; MARQUES, P.R.; GAYER, C.R.M.; VAZ, L.C.A.; NETO, J.F.N.; SABINO, K.C.C. Subacute toxicity evaluation of a hydroalcoholic extract of Pterodon pubescens seeds in mice with collagen-induced arthritis. $J$. Ethnopharmacol., v.77, n.2-3, p.159-164, 2001.

COELhO, M.G.; SABINO, K.C.; DALMAU, S.R. Immunomodulatory effects of sucupira (Pterodon pubescens) seed infusion on collagen-induced arthritis. Clin. Exp. Rheumatol., v.22, n.2, p.213-218, 2004.

COELHO, L.P.; REIS, P.A.; CASTRO, F.L.; GAYER, C.R.M.; LOPES, C.S.; SILVA, M.C.C.; SABINO, K.C.C.; TODESCHINI, A.R.; COELHO, M.G.P. Anti-nociceptive properties of ethanolic extract and fractions of Pterodon pubescens Benth. seeds. J. Ethnopharmacol., v.98, n.1-2, p.109-116, 2005.

DE OMENA, M.C.; BENTO, E.S.; DE PAULA, J.E.; SANT'ANA, A.E. Larvicidal diterpenes from Pterodon polygalaeflorus. Vector Borne Zoonotic Dis., v.6, n.2, p.216-222, 2006.

DEMUNER, A.J.; BARBOSA, L.C.A.; VELOSO, D.P.; ALVES, D.L.F.; HOWARTH, O.W. Structure and plant growth regulatory activity of new diterpenes from Pterodon polygalaeflorus. J.Nat.Prod., v.59, n.8, p.770-772, 1996.
DIAS, F. D.; TAKAHASHI, C.S.; SAKAMOTO-HOJO, E.; VICHNEWSKI, W.; SARTI, S.J. Genotoxicity of the natural cercaricides "sucupira" oil and eremanthine in mammalian cells in vitro and in vivo. Environ. Mol. Mutagen., v.26, n.4, p.338-344, 1995.

DOS SANTOS FILHO, D.; SARTI, S.J.; KATZ, N.; ARAÚJO, N.; ROCHA FILHO, P.A.; ABREU, J.E.; BORTOLIN, M.E. Chemoprophylactic activity of soaps containing essential oil from the fruits of Pterodon pubescens in Schistosomiasis mansoni. Mem. Inst. Oswaldo Cruz, v.82, suppl.4, p.343$345,1987$.

DOS SANTOS FILHO, D.; VICHNEWSKI, W.; BAKER, P.M.; GILBERT, B. Prophylaxis of Schistosomiaris. Diterpenes from Pterodon pubescens. An. Acad. Bras. Ciênc., v.44, n.1, p.45-49, 1972.

DUARTE, I.D.G.; NAKAMURA-CRAIG, M.; FERREIRAALVES, D.L. Possible participation of endogenous opioid peptides on the mechanism involved in analgesia induced by vouacapan. Life Sci., v.50, p.891-897, 1992.

DUARTE, I.D.; FERREIRA-ALVES, D.L.; VELOSO, D.P.; NAKAMURA-CRAIG, M. Evidence of the involvement of biogenic amines in the anti-nociceptive effect of a vouacapan extracted from Pterodon polygalaeflorus Benth. J. Ethnopharmacol., v.55, n.1, p.13-18, 1996.

DUTRA, R.C.; TREVIZANI, R.; PITTELLA, F.; BARBOSA, N.R. Anti-nociceptive activity of the essential oil and fractions of Pterodon emarginatus Vogel seeds. Lat. Am. J. Pharm., v.27, n.6, p.865-870, 2008a.

DUTRA, R.C.; LEITE, M.N.; BARBOSA, N.R. Quantification of Phenolic Constituents and Antioxidant Activity of Pterodon emarginatus Vogel seeds. Int. J. Mol. Sci., v.9, n.4, p.606-614, 2008b.

DUTRA, R.C.; BRAGA, F.G.; COIMBRA, E.C.; SILVA, A.D.; BARBOSA, N.R. Antimicrobial and leishmanicidal activities of seeds of Pterodon emarginatus. Braz. J. Pharmacogn., v.19, n.2A, p.429-435, 2009a.

DUTRA, R.C.; FAVA, M.B.; ALVES, C.C.; FERREIRA, A.P.; BARBOSA, N.R. Antiulcerogenic and anti-inflammatory activities of the essential oil from Pterodon emarginatus seeds. J. Pharm. Pharmacol., v.61, n.2, p.243-250, 2009 b. 
DUTRA, R.C.; PITTELLA, F.; FERREIRA, A.S.; LARCHER, P.; FARIAS, R.E.; BARBOSA, N.R. Healing effect of Pterodon emarginatus seeds in experimental models of cutaneous ulcers in rabbits. Lat. Am. J. Pharm., v.28, n.3, p.375-382, 2009c.

EUZEBIO, F.P.G.; DOS SANTOS, F.J.L.; PILÓ-VELOSO, D.; RUIZ, A.L.T.G.; CARVALHO, J.E.; FERREIRA-ALVES, D.L.; DE FATIMA, A. Effect of $6 \alpha, 7 \beta$-dihydroxyvouacapan$17 \beta$-oic acid and its lactone derivatives on the growth of human cancer cells. Bioorg. Chem., v.37, n.3, p.96-100, 2009.

EVANGELISTA, G.L.; COELHO-DE-SOUZA, A.N.; SANTOS, C.F.; LEAL-CARDOSO, J.H.; LOPES, E.A.B.; DOS SANTOS, M.V.; LAHLOU, S.; MAGALHÃES, P.J.C. Essential oil of Pterodon polygalaeflorus inhibits electromechanical coupling on rat isolated trachea. $J$. Ethnopharmacol., v.109, n.3, p.515-522, 2007.

FASCIO, M.; GILBERT, B.; MORS, W.B.; NISHIDA, T. Two new diterpenes from Pterodon pubescens. An. Acad. Bras. Ciênc., suppl.42, p.97-101, 1970.

FASCIO, M.; MORS, W.; GILBERT, B.; MAHAJAN, M.B.; MONTEIRO, M.B.; SANTOS FILHO, D.; VICHNEWSKI, W. Diterpenoid furans from Pterodon species. Phytochemistry, v.15, n.1, p.201-203, 1975.

GALINA, E.; GOTTLIEB, O.R. Chemistry of Brazilian Leguminosae. XLVI Isoflavones from Pterodon appariciori. Phytochemistry, v.13, n.11, p.2593-2595, 1974.

HANSEN, D.; MACEDO-RIBEIRO, S.; VERÍSSIMO, P.; YOO-IM, S.; SAMPAIO, M.U.; OLIVA, M.L.V. Crystal structure of a novel cysteinless plant Kunitz-type protease inhibitor. Biochem. Biophys. Res. Commun., v.360, n.4, p.735-740, 2007.

KATZ, N.; DOS SANTOS FILHO, D.; SARTI, S.J.; MENDES, N.M.; ROCHA FILHO, P.A.; ARAÚJO, N. Chemoprophylactic activity on Schistosomiasis mansoni of soaps containing essential oil from the fruits of Pterodon pubescens. Rev. Inst. Med. Trop., v.35, n.2, p.183-191,1993.

LEAL, L.K.; FERREIRA, A.A.; BEZERRA, G.A.; MATOS, F.J.; VIANA, G.S. Anti-nociceptive, anti-inflammatory and bronchodilator activities of Brazilian medicinal plants containing coumarin: a comparative study. $J$. Ethnopharmacol., v.70, n.2, p.151-159, 2000.
LEONHARDT, V.; LEAL-CARDOSO, J.H.; LAHLOU, S.; ALBUQUERQUE, A.A.C.; PORTO, R.S.; CELEDÔNIO, N.R.; OLIVEIRA, A.C.; PEREIRA, R.F.; SILVA, L.P.; GARCIA-TEÓFILO, T.M.N.; SILVA, A.P.F.S.; MAGALHÃES, P.J.C.; DUARTE, G.P.; COELHO-DESOUZA, A.N. Antispasmodic effects of essential oil of Pterodon polygalaeflorus and its main constituent $\beta$-caryophyllene on rat isolated ileum. Fundam. Clin. Pharmacol., v.24, n.6, p.749-758, 2010.

MAHAJAN, J.R.; MONTEIRO, M.B. New diterpenoids from Pterodon emarginatus. An. Acad. Bras. Ciênc., v.42, (Supplement), p.103-107, 1970.

MAHAJAN, J.R.; MONTEIRO, M.B. New diterpenoids from Pterodon emarginatus. An. Acad. Bras. Ciênc., v.44, n.1, p.51-53, 1972.

MAHAJAN, J.R.; MONTEIRO, M.B. New diterpenoids from Pterodon emarginatus. J. Chem. Soc. Perkin Trans.I, p.520525, 1973.

MARQUES, D.D.; MACHADO, M.I.L.; CARVALHO, M.G.; MELEIRA, L.A. DA C.; BRAZ-FILHO, R. Isoflavonoids and triterpenoids isolated from Pterodon polygalaeflorus. J. Braz. Chem. Soc., v.9, n.3, p.295-301, 1998.

MENNA-BARRETO, R.F.S.; LARANJA, G.A.T.; SILVA, M.C.C.; COELHO, M.G.P.; PAES, M.C.; OLIVEIRA, M.M.; CASTRO, S.L. Anti-Trypanosoma cruzi activity of Pterodon pubescens seed oil: geranylgeraniol as the major bioactive component. Parasitol. Res., v.103, n.1, p.111$117,2008$.

MORAES, W.F.; MATOS, L.G.; NASCIMENTO, M.V.M.; PAULA, J.R.; BARA, M.T.F.; CUNHA, L.C.; VALADARES, M.C.; COSTA, E.A. Anti-inflammatory and anti-nociceptive effects of Pterodon emarginatus stem bark alcohol extract. Pharm. Biol., v.47, n.2, p.146-150, 2009.

MORS, W.B.; PELLEGRINO, J.; DOS SANTOS FILHO, M.F. Ação profilática do óleo dos frutos de SucupiraBranca, Pterodon pubescens Benth, contra a infecção pelo Schistosoma mansoni. An. Acad. Bras. Ciênc., suppl.38, p.325-330, 1966.

MORS, W.B.; SANTOS, M.F.; MONTEIRO, H.B. Chemoprophyloactic agent in schistosomiasis: 14,15-epoxygeranylgeraniol. Science, v.157, n.3791, p.950-951, 1967. 
NETO, J.J. Contribuição ao Estudo Farmacognóstico dos frutos de Pterodon pubescens Bentham. Parte IIIIdentificação cromatográfica em fase gasosa, química e ação microbiológica do óleo do fruto. Rev. Fac. Farm. Odontol., Araraquara, v.10, n.2, p.317-327, 1976.

NUNAN, E.A.; CARVALHO, M.G.; PILÓ-VELOSO, D.; TURCHETTI-MAIA, R.M.M.; FERREIRA-ALVES, D.L. Furane diterpenes with anti- and pro-inflammatory activity. Rev. Bras. Pesq. Med. Biol., v.15, n.6, p.450-451, 1982.

OLIVEIRA, D.M.T.; PAIVA, E.A.S. (2005) Anatomy and Ontogeny of Pterodon emarginatus (FABACEAE: FABOIDEAE) Seed. Braz. J. Biol., v.65, n.3, p.483-494, 2005.

PIMENTA, A.T.A.; SANTIAGO, G.M.P.; ARRIAGA, A.M.C.; MENEZES, G.H.A.; BEZERRA, S.B. Estudo fitoquímico e avaliação da atividade larvicida de Pterodon polygalaeflorus Benth (Leguminosae) sobre Aedes aegypti. Rev. Bras. Farm., v.16, n.4, p.501-505, 2006.

SABINO, K.C.; GAYER, C.R.; VAZ, L.C.; SANTOS, L.R.; FELZENSZWALB, I.; COELHO, M.G. In vitro and in vivo toxicological study of the Pterodon pubescens seed oil. Toxicol. Lett., v.108, n.1, p.27-35, 1999a.

SABINO, K.C.; CASTRO, F.A.; OLIVEIRA, J.C.; DALMAU, S.R.; COELHO, M.G. Successful treatment of collageninduced arthritis in mice with a hydroalcohol extract of seeds of Pterodon pubescens. Phytother. Res., v.13, n.7, p.613-615, 1999b.

SANTOS FILHO, D.; GILBERT, B. Prophylaxis of Schistosoma by the fruit oil of Pterodon pubescens Benth. [Profilaxia de esquistossomose pelo óleo de Pterodon pubescens Benth: Dois novos diterpenos]. Bol. Fac. Farm. Odontol. Ribeirão Preto, v.6, n.1, p.142-149, 1969.
SILVA, M.C.; GAYER, C.R.; LOPES, C.S.; CALIXTO, N.O.; REIS, P.A.; PASSAES, C.P.; PAES, M.C.; DALMAU, S.R.; SABINO, K.C.; TODESCHINI, A.R.; COELHO, M.G. Acute and topic anti-edematogenic fractions isolated from the seeds of Pterodon pubescens. J. Pharm. Pharmacol., v.56, n.1, p.135-141, 2004.

SILVA, D.P.; CASADO-FILHO, E.L.; CORREAA, A.S.R.; FARIAS, L.R.; BLOCH, JR., C.; GROSSI DE SÁ, M.F.; MENDES, P.A.M.; QUIRINO, B.F.; NORONHA, E.F.; FRANCO, O.L. Identification of an $\alpha$-Amylase Inhibitor from Pterodon pubescens with Ability To Inhibit Cowpea Weevil Digestive Enzymes. J. Agric. Food Chem., v.55, n.11, p.4382-4387, 2007.

SPINDOLA, H.M.; CARVALHO, J.E.; RUIZ, A.L.T.G.; RODRIGUES, R.A.F.; DENNY, C.; SOUSA, I.M.O.; TAMASHIRO, J.Y.; FOGLIO, M.A. Furanoditerpenes from Pterodon pubescens Benth with selective in vitro anticancer activity for prostate cell line. J.Braz.Chem. Soc., v.20, n.3., p.569-575, 2009.

SUÁREZ, G.R.; ENGLEMAN, E.M. Depósito de taninos en la testa de Amaranthus hypochondriacus L. (alegria). Agrociencia, v.42, p.35-50, 1980.

TORRENEGRA, R.; BAUEREIB, P.; ACHENBACH, H. Homoormosanine-Type Alkaloids from Bowdichia Virgiloides. Phytochemistry, v.28, n.8, p.2219-2221, 1989.

VIEIRA, C.R.; MARQUES, M.F.; SOARES, P.R.; MATUDA, L.; DE OLIVEIRA., C.M.A.; KATO, L.; DA SILVA, C.C.; GUILLO, L.A. Antiproliferative activity of Pterodon pubescens Benth. seed oil and its active principle on human melanoma cells. Phytomedicine, v.15, n.6-7, p.528-532, 2008.

Received for publication on $06^{\text {th }}$ Jan 2010. Accepted for publication on $16^{\text {th }}$ April 2010. 